\title{
Evaluation of intensified provider initiated testing and counselling program in Harare City, 2017-2018
}

Edias Mandere ${ }^{1}$, More Mungati ${ }^{2}$, Gloria Gonese ${ }^{3}$, Notion Gombe ${ }^{4}$, Tsitsi Juru ${ }^{1 *}$ (D), Simbarashe Chiwanda ${ }^{1}$, Emmanuel Govha', Gerald Shambira ${ }^{1}$ and Mufuta Tshimanga ${ }^{1}$

\begin{abstract}
Background: Knowledge of HIV status remains a challenge despite implementation of various testing strategies including provider-initiated HIV testing (PITC). Harare City intensified provider-initiated HIV testing by targeting testing all eligible clients visiting facilities to achieve the UNAIDS first 95. This study aimed at evaluating the intervention to improve its effectiveness and inform programming decisions for universal access to HIV testing.

Methods: A descriptive cross-sectional study was conducted in Harare from April to June 2019. Evaluation of the intervention was conducted using the logic model approach to assess the inputs, processes and outputs. Health workers were interviewed using an interviewer administered questionnaire. Exit interviews were conducted for eligible clients $>18$ years who refused to be tested. A checklist was used to assess the inputs used and a desk review of HIV screening and testing records was done.
\end{abstract}

Results: A total of $(n-45)$ health care workers and $(n=70)$ clients were interviewed with a response rate of $(92 \%)$ and $(84 \%)$ respectively. The median age for clients was $31(\mathrm{Q} 1=24: \mathrm{Q} 3=38)$ and median years in service for health workers was $2\left(Q_{1}=1 ; Q_{3}=26\right)$. Of the 133,899 clients who were eligible for testing after screening, 98,587 (74\%) accepted the test leaving a gap of 35,312 (26\%). However, 21/45 (47\%) of health workers indicated high workload in the morning as the major reason for the leakage. In addition, 25/70 (36\%) of the clients indicated long waiting time as the reason for opting out of HIV testing.

Conclusion and recommendation: HIV testing coverage for eligible clients was not optimal, 26\% opted out. We recommend strengthening of health facility systems such as review of patient flow, re-allocation of staff during busy HIV testing time and scaling up the use of HIV self-test kits for clients concerned with waiting time to improve HIV testing coverage.

Keywords: HIV, Eligible clients, Provider initiated testing and counselling

\footnotetext{
* Correspondence: tsitsijuru@gmail.com

'Department of Community Medicine, University of Zimbabwe, Harare, Zimbabwe

Full list of author information is available at the end of the article
}

(c) The Author(s). 2021 Open Access This article is licensed under a Creative Commons Attribution 4.0 International License, which permits use, sharing, adaptation, distribution and reproduction in any medium or format, as long as you give appropriate credit to the original author(s) and the source, provide a link to the Creative Commons licence, and indicate if changes were made. The images or other third party material in this article are included in the article's Creative Commons licence, unless indicated otherwise in a credit line to the material. If material is not included in the article's Creative Commons licence and your intended use is not permitted by statutory regulation or exceeds the permitted use, you will need to obtain permission directly from the copyright holder. To view a copy of this licence, visit http://creativecommons.org/licenses/by/4.0/. The Creative Commons Public Domain Dedication waiver (http://creativecommons.org/publicdomain/zero/1.0/) applies to the data made available in this article, unless otherwise stated in a credit line to the data. 


\section{Background}

The World Health Organization (WHO) and the Joint United Nations Programme on HIV/AIDS (UNAIDS) recommended universal access to knowledge of HIV status under the following $5 \mathrm{C}$ 's consent, confidentiality, counselling, correct results and connections [1]. Provider Initiated Testing and Counselling (PITC) opt- out strategy was recommended by WHO in 2007 for high HIV burden countries (mostly in the Sub-Saharan Africa region) to scale up access to HIV testing [2]. Despite the adoption of the recommendation about 30\% of people living with HIV globally were still unaware of their HIV status by the end of 2016 [1].

By the end of 2017, an estimated 9.4 million (25\%) of people living with HIV were still unaware of their status [3]. Regionally, about $24 \%$ of people living with HIV in Southern Africa were unaware of their HIV status by the end of 2017 [4]. In Zimbabwe, the Population-Based HIV Impact Assessment Survey (ZIMPHIA) 2016, estimated that 1, 3 million people were living with HIV while $74 \%$ knew their HIV status against a target of $90 \%$ giving a national gap of $16 \%$ people yet to be identified [5]. Staveteig et al., 2017 reported a 69\% HIV testing coverage calculated from 16 African countries, which leaves a significant number of eligible people not tested [6].

The Zimbabwe National Guidelines on HIV Testing and Counselling clearly states that, "PITC services should be provided to all adults, adolescents and children attending all health facilities as the recommended standard of care" [7]. In response, Harare City health department intensified Provider Initiated HIV Testing (PITC) with support from partners to reduce leakages from HIV testing among eligible clients. As part of this intervention, Harare city health department was provided with additional human resources, data collection tools, tents to increase testing space, tables/chairs, and capacity building of clinic staff. The intensified PITC intervention involved screening all clients visiting the facility individually for HIV testing eligibility. Clients who are eligible are offered HIV testing and if they agree, the test is performed. The availability of additional staff was meant to ensure that all clients who need the services are assisted on time. Implementing facilities were provided with strategic information tools for data capturing, analysis, and reporting. By intensifying PITC eligible people visiting health facilities are tested for HIV and enrolled into care.

Despite implementing this intensified PITC model in Zimbabwe HIV testing coverage remains below 100\% among eligible clients visiting clinics. According to a PITC study conducted in Hurungwe, Zimbabwe by Musarandega et al., 2018, 77.7\% of children who were eligible for HIV testing were missed [8]. In Harare 35\% of clients screened at OPD were eligible for HIV testing, but only $61 \%$ of those eligible opted in for HIV testing. It is against this background that we evaluated the intensified PITC in Harare and came up with recommendations that are aimed at improving the service.

\section{Methods}

\section{Study design}

We used a descriptive cross-sectional study design and conducted a process evaluation using the logic model approach. The logic model approach was preferred because it clearly depict the relationship between the problem, resources allocated and the interventions implemented to achieve the desired outcome (Fig. 1) [9]. This evaluation assessed the inputs, processes and outputs used to implement the intensified PITC intervention in Harare City .

\section{Study setting}

The study was conducted at clinics managed by the Harare City Health Services Department. City of Harare is the capital city of Zimbabwe resident to 1, 598,830 million people located in in 135 suburbs with 534,106 thousand private households [10]. A total of 42 public health facilities comprising of 12 polyclinics, 6 family health services clinics, 7 primary care clinics, 15 satellite clinics, and 2 infectious disease hospitals provide health care to residents and no-residents of Harare [11]. At each facility there are Nurses, Nursing Assistants, and Counsellors who provide HIV testing services to clients. Clients testing HIV-positive are then linked to ART and followed-up.

\section{Sampling and participants}

Fifteen Health facilities out of the 42 in City of Harare were selected for the study. The 42 facilities were allocated unique numbers and Microsoft excel was used to randomly select the first 13 facilities. Additional 2 infectious disease hospitals were purposively selected and included in the study because of their high number of clients. Health workers found on duty were purposively recruited while Nurse Managers at participating health facilities were interviewed as key informants. Clients who opted out of HIV testing were identified using convenience sampling and interviewed on exit from the facility.

\section{Data collection and analysis}

A structured interviewer administered questionnaire specifically designed for this study was used to determine the reasons for failing to meet the testing target by health workers (Supplementary file 1). A checklist was used to assess availability and adequacy 


\begin{tabular}{|c|c|c|c|c|}
\hline Inputs & Process & Outputs & Outcome & Impact \\
\hline $\begin{array}{l}\text { Human resources } \\
\text { for Health }\end{array}$ & \multirow{3}{*}{$\begin{array}{l}\text { Sensitisation } \\
\text { of Health } \\
\text { workers on } \\
\text { IPITC }\end{array}$} & \multirow{2}{*}{$\begin{array}{l}\text { Number of health } \\
\text { workers sensitised on } \\
\text { IPITC }\end{array}$} & \multirow{3}{*}{$\begin{array}{l}\% \text { staff } \\
\text { trained in } \\
\text { IPITC }\end{array}$} & \multirow{9}{*}{$\begin{array}{l}\text { Impact } \\
\text { All clients } \\
\text { visiting the } \\
\text { facilities } \\
\text { who are } \\
\text { eligible are } \\
\text { tested for } \\
\text { HIV }\end{array}$} \\
\hline HIV Test Kits & & & & \\
\hline $\begin{array}{l}\text { HIV Screening } \\
\text { tool/registers }\end{array}$ & & \multirow[t]{2}{*}{$\begin{array}{l}\text { Number of support } \\
\text { visits done }\end{array}$} & & \\
\hline Computers & \multirow{2}{*}{$\begin{array}{l}\text { Health } \\
\text { Education }\end{array}$} & & \multirow{4}{*}{$\begin{array}{l}\% \text { of clients } \\
\text { tested for HIV }\end{array}$} & \\
\hline Airtime & & \multirow{2}{*}{$\begin{array}{l}\text { Number of Health } \\
\text { Education sessions } \\
\text { done }\end{array}$} & & \\
\hline Stationery & \multirow[t]{2}{*}{$\begin{array}{l}\text { Support and } \\
\text { supervision }\end{array}$} & & & \\
\hline Transport & & \multirow{2}{*}{$\begin{array}{l}\text { Number of eligible } \\
\text { clients identified }\end{array}$} & & \\
\hline $\begin{array}{l}\text { Policies and } \\
\text { Guidelines }\end{array}$ & \multirow{2}{*}{$\begin{array}{l}\text { Monitoring } \\
\text { and } \\
\text { evaluation }\end{array}$} & & \multirow{2}{*}{$\begin{array}{l}\% \text { of HIV } \\
\text { positive } \\
\text { clients } \\
\text { identified }\end{array}$} & \\
\hline Working space & & $\begin{array}{l}\text { Number of eligible } \\
\text { clients tested for HIV }\end{array}$ & & \\
\hline
\end{tabular}

Fig. 1 Logical model for intensified PITC Intervention, Harare City 2017-2018

of inputs used to implement the project. In this study adequacy was defined as an average of above (95\%) achievement in terms of availability of inputs. The checklist assessed human resources, consumables, policies \& guidelines, monitoring \& evaluation tools, communication, and HIV testing space. A desk review of the reports and registers was conducted to evaluate the processes and outputs of the IPITC intervention. The review of records provided Information such as number of clients screened/eligible for HIV testing, number of clients accepted and tested for HIV and number of clients tested HIV positive (positivity rate). Exit interviews were conducted for eligible clients who opted out of HIV testing, to determine the reasons for refusing testing. The researcher asked the following questions for health workers and clients, respectively. What are some of the main challenges that you experienced for not meeting your HIV testing target? and What are your reasons for opting out of HIV testing?

Quantitative data was analysed using Epi-info version 7 to calculate frequencies, means and calculation of proportions. Qualitative data was sorted and analyzed manually by coding respondent's views into similar thematic areas. We assigned labels in the form of words or phrases to represent recurring themes in participants responses. Summaries of this data was presented as frequencies and proportions of responses.

\section{Permissions and ethical considerations}

Permission to conduct the study was obtained from the University of Zimbabwe, Department of Community Medicine, and the Health Director City of Harare. Written consent was obtained from study participants before the interviews were conducted. Privacy and confidentiality were maintained throughout the study, participants were asked if they agree to be enrolled in the study and interviews were conducted in a closed room at the health facilities. Each interview took less than 15 min to complete. Anonymity was guaranteed by not writing participants names on the questionnaires and all questionnaires were kept locked by the investigator.

\section{Results}

A total of $(n=45)$ health workers and $(n=70)$ clients were interviewed with a response rate of $(92 \%)$ and (84\%) respectively. Median age for clients was $31(\mathrm{Q} 1=24: \mathrm{Q} 3=38)$ and the median years in service for health workers was $2\left(\mathrm{Q}_{1}=1 ; \mathrm{Q}_{3}=26\right)$. Majority of the participants were females constituting 49 (70\%) and males 21 (30\%) respectively. More than half $50(71 \%)$ of the participants attained secondary level of education. Fifty-four percent $(n=70)$ of the participants were married and half of them $35(50 \%)$ were not employed. Twenty eight percent $(n=70)$ were earning a monthly income of between 100 and 500 Zimbabwean dollar (Table 1).

The inputs used to implement the intervention were adequate (96.8\%), adequacy was defined as an average of above (95\%) achievement in terms of availability of inputs. Only $1 / 15$ (10\%) facilities had a stock out of determine test kits once during the 1 year. Three out of fifteen $(20 \%)$ of the facilities had their phone not working. Two out of fifteen (14\%) of the facilities reported inadequate working space for testing clients especially during peak hours in the morning (Table 2).

The target for processes used to implement the intervention were fairly achieved, however there were no 
Table 1 Demographic characteristics of clients interviewed, Harare City 2017-2018

\begin{tabular}{|c|c|c|}
\hline Variable & Frequency $n=70$ & (\%) \\
\hline \multicolumn{3}{|l|}{ Sex } \\
\hline Male & 21 & 30 \\
\hline Female & 49 & 70 \\
\hline \multicolumn{3}{|l|}{ Age } \\
\hline 18-24 Years & 18 & 26 \\
\hline 24-49 Years & 49 & 70 \\
\hline$<50$ Years & 3 & 4 \\
\hline Median age years: 31 & $31(\mathrm{Q} 1=24: \mathrm{Q} 3=38)$ & \\
\hline \multicolumn{3}{|l|}{ Highest level of education } \\
\hline Primary & 12 & 18 \\
\hline Secondary & 50 & 71 \\
\hline Tertiary & 8 & 11 \\
\hline \multicolumn{3}{|l|}{ Marital status } \\
\hline Single & 20 & 28 \\
\hline Married & 38 & 54 \\
\hline Divorced & 8 & 11 \\
\hline Widowed & 4 & 5 \\
\hline \multicolumn{3}{|l|}{ Employment status } \\
\hline Formally employed & 10 & 14 \\
\hline Informal employment & 25 & 36 \\
\hline Not employed & 35 & 50 \\
\hline \multicolumn{3}{|l|}{ *Monthly income (ZW\$) } \\
\hline$<\$ 100$ & 26 & 37 \\
\hline $100-500$ & 28 & 40 \\
\hline$>500$ & 16 & 23 \\
\hline
\end{tabular}

*ZW\$ Zimbabwe dollar

Information Education and Communication (IEC) materials for distribution to clients to inform them about the services (Table 3).

On outputs, the study showed that, $44 / 45$ (98\%) of health workers were trained to implement the PITC intervention at its inception in 2017. New staff who joined Harare City were trained on the job, however there were no refresher trainings for the initial group. Desk review results and program data showed that 133 , 899 clients were eligible for testing after screening but only 98,587 (74\%) of then opted in for testing leaving a gap of $35,312(26 \%)$. The positivity rate for those tested was $7123(7 \%)$.(Table 4$)$.

Thirty six percent $(n=70)$ of the respondents who were eligible indicated that long waiting time was the major reason for opting out of HIV testing. The other reasons cited were fear of a positive result $15(21 \%)$ and perceived low risk of contracting HIV was cited by 15 (21\%) of the respondents (Table 5). A quote from one of the participants, "I am eligible for testing but could not wait for the test because the queue is too long, I will come back sometime" Health workers interviewed indicated high workload $21(47 \%)$ especially in the morning, shortage of staff $14(31 \%)$ and poor patient flow $9(20 \%)$ as major reasons for not meeting the target (Table 6). One of the nurses said, "The demand for testing is usually high in the morning after screening, we need additional testers to ease the workload".

\section{Discussion}

We evaluated the intensified PITC intervention in 15 City of Harare clinics for the period October 2017 to September 2018. Several areas were noted to have gaps affecting proper implementation of the intensified PITC intervention. The inputs injected and processes used to implement the intervention were adequate to meet the set objectives. In this study adequacy was defined as an average of above (95\%) achievement in terms of availability of inputs. However, some of the facilities did not have adequate testing space. The challenge was mainly experienced in the morning due to the high number of clients waiting to be tested after the eligibility screening process. Training of more health workers to beef up testing points in the morning and scaling up HIV self-testing may be necessary to increase uptake.

Unavailability of IEC material was a major bottleneck which may have negatively impacted on the intervention resulting in more clients opting out of HIV testing due to lack of information. The findings were consistent with the results of a study conducted in Ethiopia 2017 which showed that, the major reasons for not accepting the HIV test were poor access to correct understandable PITC information from health workers [12]. Hence, demand creation in the form of awareness campaigns and availing IEC materials in strategic positions is highly recommended.

During the period reviewed, a significant number of clients who were eligible for HIV testing at the 15 facilities were not tested for HIV. This is of great concern, considering the difficulties in convincing clients to come to health facilities for HIV testing. When they come to the facilities, the health system should ensure services are provided. Some of the health system factors identified to affect HIV testing in this study were too few testers and inadequate working space especially during peak hours. While some of the client related reasons were fear of a positive result and perceived low risk of contracting HIV. These important findings provide an opportunity for program managers to develop strategies to address identified testing gaps. The interventions will eventually contribute to the achievement of the UNAIDS 
Table 2 Inputs used for implementation of intensified PITC Intervention, Harare City 2017-2018

\begin{tabular}{|c|c|c|c|}
\hline Inputs & Target & Achievement & $\%$ achievement \\
\hline \multicolumn{4}{|l|}{ Human resources } \\
\hline Ol Nurses & 30 & 30 & 100 \\
\hline Primary care counsellors & 60 & 60 & 100 \\
\hline Data entry clerks & 15 & 15 & 100 \\
\hline \multicolumn{4}{|l|}{ Consumables } \\
\hline HIV test kits (Availability at facility) & 15(facilities) & 14 & 90 \\
\hline Gloves (Availability at facility) & 15(facilities) & 15 & 100 \\
\hline \multicolumn{4}{|l|}{ M \& Tools } \\
\hline Registers & 15(facilities) & 15 & 100 \\
\hline Computers & 15(facilities) & 15 & 100 \\
\hline \multicolumn{4}{|l|}{ Policies and guidelines } \\
\hline HIV testing guidelines & 15(facilities) & 15 & 100 \\
\hline HIV testing algorithm & 15(facilities) & 15 & 100 \\
\hline Eligibility criteria SOP & 15(facilities) & 15 & 100 \\
\hline \multicolumn{4}{|l|}{ Communication } \\
\hline Landline working & 15(facilities) & 12 & 80 \\
\hline Cell phones & 15(facilities) & 15 & 100 \\
\hline Airtime & 15(facilities) & 15 & 100 \\
\hline \multicolumn{4}{|l|}{ *Adequate working space } \\
\hline Rooms/Tents & 15(facilities) & 13 & 86 \\
\hline
\end{tabular}

* Adequacy of inputs is defined as an average of above $95 \%$ achievement in terms of availability of inputs

first 90 which aims at identifying $90 \%$ of people living with HIV by 2020 [13].

Almost half of the health workers interviewed reported that high workload was the major reason for not meeting the target of testing all eligible clients. Despite the Human Resources for Health (HRH) support from the implementing partner, majority of the respondents indicated shortage of staff as the reason for not meeting their target. The challenge of workload was experienced mostly during the morning when the number of clients to be tested was high. The other contributory factor was that not all nurses were trained to test for HIV. The above findings were consistent with results of a study conducted in subSaharan Africa which was reviewing operational implementation of PITC program. Human resources and health systems management issues affected implementation of PITC [14]. Poor patient flow was also reported by a third of the respondents indicating the need for managers to have sound knowledge of the program to improve the system. Managers should ensure availability of adequate human and material resources to prevent interruption of services. A study conducted in South Africa in 2013 showed that strong leadership and implementation support by managers and good knowledge of the program by nurses aided in achieving the desired outcome [15].

Despite having been provided with information concerning the need to have an HIV test, a third of the eligible respondents who were individually screened using

Table 3 Processes used to implement intensified PITC Intervention Harare City, 2017-2018

\begin{tabular}{llll}
\hline Variable & Target & Achievement & \% achievement \\
\hline Training of Health Workers & 1 (session) & 1 & 100 \\
Health Education & 15 (Facilities) & 15 & 100 \\
Distribution of IEC material & 15 (Facilities) & 0 & 0 \\
Screening of eligible clients & 15 (Facilities) & 15 & 100 \\
HIV Testing (Quality Assurance) & 15 (Facilities) & 15 & 100 \\
Support and Supervision & 15 (Facilities) & 15 & 100 \\
Documentation and reporting & 15 (Facilities) & 15 & 100 \\
\hline
\end{tabular}


Table 4 Outputs of the intensified PITC intervention, Harare City 2017-2018

\begin{tabular}{llll}
\hline Variable & Target & Achievements & \%Achievements \\
\hline $\begin{array}{l}\text { Health care workers } \\
\text { trained on IPITC }\end{array}$ & 45 & 44 & 98 \\
$\begin{array}{l}\text { Support \&Supervision } \\
\text { visits conducted }\end{array}$ & 15 (facilities) & 15 & 100 \\
$\begin{array}{l}\text { Health Education Talks } \\
\text { Conducted daily }\end{array}$ & 15 (facilities) & 15 & 100 \\
$\begin{array}{l}\text { Number eligible tested } \\
\text { for HIV. }\end{array}$ & 133,899 & 98,587 & 74 \\
$\begin{array}{l}\text { Number tested HIV } \\
\text { Positive }\end{array}$ & $6 \%$ yield & 7123 & 7 yield \\
\hline
\end{tabular}

a screening tool still opted out. Respondents reported that the waiting time before being tested by the Primary Counsellor was too long especially in the morning. However, when clients wait too long before they are tested, they will opt out. Similarly, more than half of the respondents in a study conducted in Tanzania reported too many patients waiting for services as a reason for not testing. Another $46 \%$ in the same study reported inadequate space as the barriers to HIV testing [16]. We also found out that majority of the respondents did not agree to testing because of perceived low risk of contracting HIV and fear of a positive result. The self-risk perception to HIV infection was consistent with a study conducted in Ethiopian 2017 [12]. It is therefore necessary to intensify counselling so that clients are not afraid of an HIV test.

\section{Limitations}

Our study was subjected to information bias because of the sensitive nature of some responses. Participants may not have provided correct information on reasons for opting out of HIV testing to protect their relationship with nurses. However, participants were assured of confidentiality and the bias was minimised. In addition, we opted for convenience sampling because of limited time

Table 5 Reasons for opting out of HIV Testing by eligible clients screened in City of Harare, April 2019

\begin{tabular}{|c|c|c|}
\hline Variable & Frequency $n=70$ & $(\%)$ \\
\hline \multicolumn{3}{|l|}{ Clients eligible for HIV testing } \\
\hline Long waiting time before an HIV test & 25 & 36 \\
\hline Health workers attitudes (Client Perception) & 2 & 3 \\
\hline Fear of a positive result & 15 & 21 \\
\hline Lack of privacy (Documentation of names) & 5 & 7 \\
\hline Perceived low risk of contracting HIV & 15 & 21 \\
\hline To consult partner & 2 & 3 \\
\hline Reason not specified & 6 & 9 \\
\hline
\end{tabular}

Table 6 Reasons for failing to meet the intensified PITC target, Harare City, 2017-2018

\begin{tabular}{lll}
\hline Variable & Frequency $\boldsymbol{n = 4 5}$ & (\%) \\
\hline Health Workers & 21 & 47 \\
High workload & 9 & 20 \\
Poor Patient flow & 14 & 31 \\
Shortage of staff & 1 & 2 \\
Shortage of test kits & & \\
\hline
\end{tabular}

which may have introduced selection bias and affected representativeness of the study population.

\section{Conclusion}

The findings from our study shows that HIV testing coverage for eligible clients at the clinics was not optimal due to health system and client related reasons. The testing gap will negatively impact on the achievement of UNAIDS testing targets and eventually HIV epidemic control. Awareness campaigns through distribution of information education and communication materials on the importance of testing is desirable. Health facility systems such as annual refresher trainings, review of patient flow and re-allocation of staff during busy HIV testing time and use of HIV self-test kits for clients concerned with waiting time may help to improve HIV testing coverage.

\section{Supplementary Information}

The online version contains supplementary material available at https://doi. org/10.1186/s12889-021-10485-6.

Additional file 1 : Supplementary file 1. Questionnaire with questions for health care workers and exit interview questions for clients.

\section{Abbreviations}

IPITC: Intensified Provider Initiated Testing \& Counselling; PITC: Provider Initiated Testing \& Counselling; AIDS: Acquired Immune Deficiency Syndrome; HIV: Human Immune Virus; PLWHIV: People Living with Human Immune Virus; ART: Antiretroviral therapy; ARV: Antiretroviral;

Ol: Opportunistic Infection; WHO: World Health Organisation?; UNAIDS: Joint United Nations Programme on HIV/AIDS; ZIMPHIA: Zimbabwe PopulationBased HIV Impact Assessment

\section{Acknowledgments}

I would like to express my sincere gratitude to my field supervisor, Dr. G Gonese for her guidance and support. I would also want to thank Dr. M Mungati who assisted in the preparation of this project. I would also want to express my gratitude to the Department of Community Medicine, University of Zimbabwe and Health Studies Office, Zimbabwe for all the help they rendered to me. Special thanks go to the City of Harare staff and clients who participated in this study.

\section{Authors' contributions}

EM: conception, design, acquisition, analysis and interpretation of data and drafting the manuscript. MM: conception, design, acquisition, analysis and interpretation of data and drafting the manuscript. GG: conception, design, acquisition, analysis and interpretation of data and drafting the manuscript GS: conception, design, data collection, analysis, interpretation and reviewing of manuscript draft for important intellectual content. NGT: conception, design, data collection, analysis, interpretation and reviewing of manuscript 
draft for important intellectual content. TJ: conception, design, data collection, analysis, interpretation and reviewing of manuscript draft for important intellectual content. SC: conception, design, data collection, analysis, interpretation and reviewing of manuscript draft for important intellectual content. EG: conception, design, data collection, analysis, interpretation and reviewing of manuscript draft for important intellectual content. MT: conception, design, data collection, analysis, interpretation and reviewing of manuscript draft for important intellectual content. The author(s) read and approved the final manuscript.

\section{Funding}

No funding

\section{Availability of data and materials}

The data that support the findings of this study are available from the City of Harare Department of Health Services, but restrictions apply to the availability of these data. Data are, however, available from the authors upon request and with permission from City of Harare.

\section{Declarations}

\section{Ethics approval and consent to participate}

Permission to proceed with the study was obtained from the Director of services, City of Harare and the University of Zimbabwe, Department of Community Medicine. All participants singed a written consent before being enrolled into the study.

\section{Consent for publication}

Not applicable.

\section{Competing interests}

The authors declare no competing interests whether financial or nonfinancial.

\section{Author details}

'Department of Community Medicine, University of Zimbabwe, Harare, Zimbabwe. ${ }^{2}$ Elizabeth Glaser Paediatric AIDS Foundation, Maseru, Lesotho. ${ }^{3}$ International Training \& Education Centre for Health, Harare, Zimbabwe.

${ }^{4}$ African Field Epidemiology Network, Kampala, Uganda.

Received: 9 March 2020 Accepted: 22 February 2021

Published online: 02 March 2021

\section{References}

1. WHO. UNAIDS statement on HIV testing services: new opportunities and ongoing challenges. 8

2. WHO | Guidance on provider-initiated HIV testing and counselling in health facilities [Internet]. WHO. [cited 27 Jan 2019]. Available from: https://www. who.int/hiv/pub/vct/pitc2007/en/.

3. Global HIV \& AIDS statistics - 2018 fact sheet | UNAIDS [Internet]. [cited 16 Jan 2019]. Available from: http://www.unaids.org/en/resources/fact-sheet.

4. HIV and AIDS in East and Southern Africa regional overview [Internet]. AVER T. 2015 [cited 16 Jan 2019]. Available from: https://www.avert.org/ professionals/hiv-around-world/sub-saharan-africa/overview.

5. ZIMBABWE-Factsheet.FIN_.pdf [Internet]. [cited 12 Dec 2018]. Available from: https://phia.icap.columbia.edu/wp-content/uploads/2016/11/ZIMBABWE-Fa ctsheet.FIN_.pdf.

6. Staveteig S, Croft TN, Kampa KT, Head SK. Reaching the "first 90": gaps in coverage of HIV testing among people living with HIV in 16 African countries. PLoS One. 2017;12(10):e0186316.

7. Zimbabwe: National guidelines on HIV testing and counselling. :84.

8. Musarandega R, Mutede B, Mahomva A, Nyamayaro W, Mushavi A, Lindan $C$, et al. Scaling up pediatric HIV testing by incorporating provider-initiated HIV testing into all child health services in Hurungwe District, Zimbabwe. J Acquir Immune Defic Syndr. 2018;77(1):78-85.

9. The Logic Model. The foundation to implement, study, and refine patientcentered medical home models. :12.

10. Cy POB. Zimbabwe population census 2012.:152.

11. City of Harare - Health services [Internet]. [cited 18 Jan 2020]. Available from: http://www.hararecity.co.zw/index.php/template-features/healthservices.
12. Godana W. Determinants for refusal of provider initiated HIV testing and counseling among adult opd clients In Kachabira District Health Centers, South Ethiopia: Institution based unmatched case control study. Health Syst Policy Res . 2017 4(2). [cited 27 Jan 2019]; Available from: http://www.hsprj. com/abstract/determinants-for-refusal-of-provider-initiated-hiv-testing-andcounseling-among-adult-opd-clients-in-kachabira-district-health-centerssouth-ethiopia-institution-based-unmatched-case-control-study-19028.html.

13. 90-90-90: An ambitious treatment target to help end the AIDS epidemic. :40.

14. Roura M, Watson-Jones D, Kahawita TM, Ferguson L, Ross DA. Providerinitiated testing and counselling programmes in sub-Saharan Africa: a systematic review of their operational implementation. AIDS. 2013;27(4): 617-26

15. Leon N, Lewin S, Mathews C. Implementing a provider-initiated testing and counselling (PITC) intervention in cape town, South Africa: a process evaluation using the normalisation process model. Implement Sci. 2013:8:97.

16. Ntuli AK, Kabengula JS, Msuya SE. Perceived barriers and attitudes of health care providers towards provider-initiated HIV testing and counseling in Mbeya region, southern highland zone of Tanzania. Pan Afr Med J. 2011;8: 17 [cited 2019 Jan 26]. Available from: https://www.ncbi.nlm.nih.gov/pmc/a rticles/PMC3221402/.

\section{Publisher's Note}

Springer Nature remains neutral with regard to jurisdictional claims in published maps and institutional affiliations.
Ready to submit your research? Choose BMC and benefit from:

- fast, convenient online submission

- thorough peer review by experienced researchers in your field

- rapid publication on acceptance

- support for research data, including large and complex data types

- gold Open Access which fosters wider collaboration and increased citations

- maximum visibility for your research: over $100 \mathrm{M}$ website views per year

At BMC, research is always in progress.

Learn more biomedcentral.com/submissions 